\title{
A Review on High Performance Thin Layer Chromatography Methods and Validation Parameters for Quantification of Andrographolide from Andrographis paniculata and its Marketed Formulations
}

Shweta Parihar ${ }^{1}$, Sonia Hooda ${ }^{1}$, Saloni Kakkar ${ }^{2}$, Meenu Bhan ${ }^{2 *}$

${ }^{1}$ Research Scholar, Department of Pharmaceutical Sciences, Maharshi Dayanand University, Rohtak, Haryana, India

${ }^{2}$ Assistant Professor, Department of Pharmaceutical Sciences, Maharshi Dayanand University, Rohtak, Haryana, India

DOI: $10.36347 /$ sajp.2022.v11i01.005

| Received: 09.12.2021 | Accepted: 14.01.2022 | Published: 22.01.2022

*Corresponding author: Meenu Bhan

Assistant Professor, Department of Pharmaceutical Sciences, Maharshi Dayanand University, Rohtak, Haryana, India

\section{Abstract}

Review Article

Andrographis paniculata is an important medicinal plant belonging to family Acanthaceae and has been used from ancient times. Andrographis paniculata is used as a traditional herbal medicine in Unani, Ayurvedic, Homeopathic, and Siddha system. It has potential to treat multiple health diseases like abortifacient, antithrombotic, expectorant, hepatoprotective and other uses also. The major marker chemical constituent found is andrographolide $(2.39 \%)$ which had many therapeutic uses. Dominancy of the herbal drug depend's on the quantity and quality of therapeutic chemical constituents present in it, which are investigated by using advanced and complex techniques. HPTLC is the advanced and sophisticated technique that can be used for the high-resolution chromatography and identify quality and quantity of therapeutic chemical constituents present in herbal drugs. HPTLC can determine the purity, quality, quantity and authenticity of the herbal crude drugs and marketed formulations very quickly. This article summarised all the relevant information regarding Andrographis paniculata and its marketed formulations was collected from various research articles, review articles and availability of Andrographis paniculata formulations in the market. Availability of various Andrographis paniculata formulations from the market were identified and reported. Literature review on quantification and qualification of marker compound Andrographolide from the Andrographis paniculata by HPTLC method with various samples of formulations and whole plant from different locations of India was also done.

Keywords: Andrographis paniculata, High Performance Thin Layer Chromatography, Andrographolide, Hepatoprotective.

Copyright $(\mathcal{C} 2022$ The Author(s): This is an open-access article distributed under the terms of the Creative Commons Attribution 4.0 International License (CC BY-NC 4.0) which permits unrestricted use, distribution, and reproduction in any medium for non-commercial use provided the original author and source are credited.

\section{INTRODUCTION}

Herbal medicine often known as phytomedicine, refers to the use of various portions of therapeutic plants. Herbal system of medicine has a long history of use outside of the realm of traditional medicine. It has become mainstream in recent decades as breakthroughs and developments in analysis and quality control, as well as advances in clinical research, have made it possible (HI Raghavendra et al., 2009; Parihar and Sharma, 2021; Telrandhe et al., 2021; Chaudhary et al., 2021). The practise of prescribing a set of standards or inherent features, consistent parameters, definitive qualitative and quantitate values that convey an assurance of quality, efficacy, safety, and repeatability for herbal medicines is known as standardisation. Standardization is a process that ensures that each packet of medicine sold has the exact amount of active ingredients and will provide the desired therapeutic effects. Standardisation of herbal formulations is necessary for determining the quality of pharmaceuticals based on the concentration of their active principle, physical, chemical standardisation, and invitro and invivo criteria (Kulkarani et al., 2019). High Performance Thin Layer Chromatography is an advanced and sophisticated method which may be use for vast range of application. It's far an effective device for high-resolution chromatography. It can trace and evaluate quantitatively the composition of chemical constituents. It's also use for immediate and smooth determination of quality, purity and authenticity of crude drugs and their marketed formulations. Validation is a vital step in knowing that the method used is reliable and reproducible. It is reliable and reliability statistics are especially depend at following conditions, namely, the reliability of the contraptions, proper trained analysts, the methods validity (Modi et al., 2016). The parameters as given with the aid of the ICH. 
The following validation parameters are commonly monitored for HPTLC approach:

1) SPECIFICITY: - This parameter can be analysing by development and establishment of relation between sample solution and interferences through ingredients present in the formulations. By using standard sample spot values and RF (Retardation Factor) values specificity can be determined (Shewiyo et al., 2012).

2) LINEARITY: - Linearity of the method can be analysing by calibration curves. The caliberation curves are constructed at different levels of concentrations. The calibration curves are plotted by taking different ranges of analyte at peak area vs concentrations (Sonia et al., 2017).

3) PRECISION: - Precision is of two types inter-day and inter-day precisions. The Intraday precision is calculated through analysing sample solutions at one-of-a-kind three ranges high, low and medium concentrations and calibration curve are made for 5 instances at equal day. Inter-day precision may be calculated with aid of studying sample solutions of three one of a kind ranges this is high, low and medium in a time interval of seven day. Height regions are calculated as \%Relative standard deviation (RSD) (Jain et al., 2014).

4) Limit of quantifications and detections: They both are also referred to as sensitivity parameters. LOD is the lowest limit/value of detection at which the drug can be detected or analyse in the sample that is which type of drugs is present in the sample either it is alkaloids containing, terpenoids etc and LOQ is the lowest limit/value of detection at which the drug quantity is detected or analyse that is how much quantity of drug quantity is present in the sample. LOD and LOQ are experimentally confirmed by diluting the recognized concentration (Shankar et al., 2020).

5) ROBUSTNESS: - By way of doing small modifications in mobile phase concentrations, as an instance in extent, time of saturation of chamber, and exchange in the distance of migration of solvent. It can be calculated in triplicate and \%Relative standard deviation (RSD). Retention factor (Rf) and peak purity are two parameters which is the reason for modifications in chromatographic conditions (Sowganya et al., 2015). 6) ACCURACY: - It can be evaluated through studies of 3 levels. Recovery experiment can be executed via including 3 one of a kind quantity of standard drug, i.e. eighty percent, hundred percent, and one hundred twenty percent of the drug, which has to be pre analyzed formulations, and the resultant is reanalyzed 6 instances.

7) Repeatability: - Repeatability or also called as measurement of peak area. It can be calculated by distinctive quantity of analyte with excessive, low and medium degrees. Calibration curve 7 times instances without changing plate position. By spotting samples and taking same range of calibration curves seven times more repeatability can do.

8) Peak Purity: - Three different levels of spectra are compared for peak purity which are: - (a) In the starting point of peak (b) When the peak is at highest position (c) In the last/end of the peak. While doing test on its pure quality, spectra of peak and slope are interlinked with each other. Peak Maximum spectra should taken most of the times with down side slope are use like a referee spectrum for determination. If the test values greater than an error of probability of one percent only then it is invalid or cancelled. It should not be rejected when the values of test and identical are more or 2.576 (Patel et al., 2012). Physicochemical properties of 'The Marker Compound Andrographolide' are given in the table 1 (Sareer et al., 2014).

Table-1: Physicochemical properties of 'The Marker Compound Andrographolide' (Sareer et al., 2014)

\begin{tabular}{|l|l|l|}
\hline S. No & PHYSICOCHEMICAL PROPERTIES & FEATURES \\
\hline $\mathbf{1}$ & NAME OF MARKER COMPOND & Andrographolide \\
\hline $\mathbf{2}$ & $\begin{array}{l}\text { INTERNATIONAL UNION OF PURE } \\
\text { AND APPLIED CHEMISTRY [IUPAC] } \\
\text { NAME }\end{array}$ & $\begin{array}{l}\text { 3-2-DecaHydro-6-Hydroxy-5-HydroxyMethyl-5,8A- } \\
\text { Dimethyl-2-MethyleneNapthyl-Ethylidene-Dihydro-4- } \\
\text { HydroxyFuran-2 [3h]-One; }\end{array}$ \\
\hline $\mathbf{3}$ & FORMULA [MOLECULAR] & $\mathrm{C}_{20} \mathrm{H}_{30} \mathrm{O}_{5}$ \\
\hline $\mathbf{4}$ & CHEMICAL CLASS AND CATOGERY & $\begin{array}{l}\text { Labdane DiterpeneLactone; } \\
\text { Unsaturated-Tri-HydroxyLactone }\end{array}$ \\
\hline $\mathbf{5}$ & PHARMACOLOGICAL CATOGERY & PNS [Pheripheral-Nervous-System] \\
\hline $\mathbf{6}$ & WEIGHT [IN MOLECULAR SYSTEM] & $350.45 \mathrm{~g} / \mathrm{m}$ \\
\hline $\mathbf{7}$ & PHYSICOLOGICAL APPEARANCE & Powder form and in solid form \\
\hline $\mathbf{8}$ & TASTE & Bitter \\
\hline $\mathbf{9}$ & COLOUR & Yellowish light and yellowish light brown \\
\hline $\mathbf{1 0}$ & Odour & No \\
\hline $\mathbf{1 1}$ & Wavelength max & $223 \mathrm{~nm}$ \\
\hline $\mathbf{1 2}$ & Melting point & $229-232^{\circ} \mathrm{C}$ \\
\hline $\mathbf{1 3}$ & Solubility & Bad solubility in water \\
\hline O 2022 Scholars Academic Journal of Pharmacy $\mid$ Published by SAS Publishers, India \\
\hline
\end{tabular}


Shweta Parihar et al., Sch Acad J Pharm, Jan, 2022; 11(1): 27-36

\begin{tabular}{|l|l|l|}
\hline S. No & PHYSICOCHEMICAL PROPERTIES & FEATURES \\
\hline $\mathbf{1 4}$ & Stability & Stable at room temperature \\
\hline $\mathbf{1 5}$ & Route of administration & Oral route, eyes contact, nasal route \\
\hline $\mathbf{1 6}$ & Chronic effect on human & Not present \\
\hline $\mathbf{1 7}$ & Product after combustion & Carbon dioxide, carbon monoxide, carbon oxides \\
\hline $\mathbf{1 8}$ & Burnable and incendiary & Flammable on increasing temp. \\
\hline $\mathbf{1 9}$ & Storage & To be kept in cool and dry place and well-ventilated place \\
\hline
\end{tabular}

\section{USES OF ANDROGRAPHIS PANICULATA}

Antiviral, anti-alzhemier (Rivera et al., 2016), antioedema (Lin et al., 2019), antipyretic, analgesic (Suebsasana et al., 2009), antifungal (Yadav et al.,2012), antimicrobial (Singha et al., 2003; Soumya et al., 2014; Tanwar et al., 2016), antibacterial (Malahubban et al., 2013; Mandal et al., 2016), antioxidant (Rafar et al., 2010; Vasu et al., 2010), anticancer (Shi et al., 2008, Lee et al.,2010, Nadiminty et al., 2010; Zhou et al., 2010; Yue et al., 2015; Tan et al., 2016; Yuan et al., 2016; Wang et al., 2016), antiinflammatory (Shen et al., 2002, Chao et al., 20019; Zou et al., 2016), hepatoprotective (Rammohan et al., 2008; Zhang et al., 2000), antihyperglycemic (Yu et al., 2003), platelet activation (Lu et al., 2011), antiulcerogenic (Madhav et al., 1995). TABLE 2 showed Marketed formulations of Andrographis paniculata according to AYUSH.

Table-2: Marketed formulations of Andrographis paniculata according to AYUSH (Ayurvedic Pharmacopoeia, Siddha Pharmacopoeia, Unani Pharmacopoeia, Homeopathic Pharmacopoeia)

\begin{tabular}{|c|c|c|c|}
\hline $\begin{array}{l}\text { AYURVEDIC } \\
\text { FORMULATIONS }\end{array}$ & $\begin{array}{l}\text { SIDDHA } \\
\text { FORMULATIONS }\end{array}$ & $\begin{array}{l}\text { HOMEOPATHY } \\
\text { FORMULATIONS }\end{array}$ & $\begin{array}{l}\text { UNANI } \\
\text { FORMULATIONS }\end{array}$ \\
\hline $\begin{array}{ll}\text { - } & \text { Kalmegh }(60 \\
\text { capsules }) \\
\text { - } & \text { Vasu vasuliv tablets } \\
\text { - } & \text { Liv d } 38 \text { tablets } \\
\text { - } & \text { Organic india } \\
\text { - } & \text { kalmegh capsules } \\
\text { DBS Kalmegh } \\
\text { - } & \text { Gyrup } \\
\text { Garlico herbal } \\
\text { kalmegh powder }\end{array}$ & 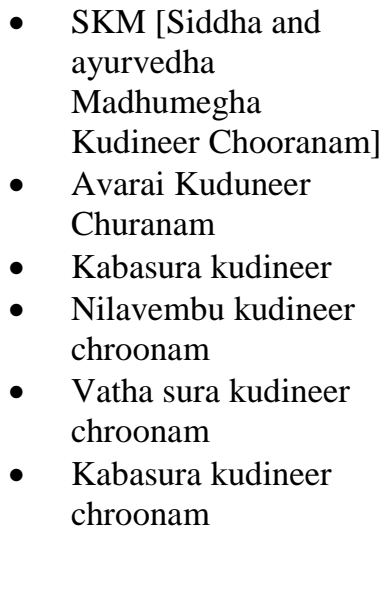 & $\begin{array}{ll}\text { - } & \text { Dr.Reckeweg Kalmegh } \\
& \text { Tinture Q } \\
\text { - } & \text { Bakson kalmegh aid } \\
\text { - } & \text { SBL Homeopathic } \\
& \text { kalmegh drops }(30 \mathrm{ml}) \\
\text { - } & \text { SBL Andrographis } \\
\text { paniculata mother tincture } & \\
\text { Q } & \text { Wheezal kalmegh drops } \\
\text { - } & \text { Dr. Willmar Schwabe } \\
\text { Andrographis paniculata } \\
\text { Q } \\
\text { Syrup kalmegh } \\
\text { homeopathic } \\
\text { medicine, } 200 \mathrm{ml} \text { Liquids }\end{array}$ & $\begin{array}{ll}\text { - } & \text { Arq-e-Chiraita } \\
\text { - } & \text { Majoon-e-Chiraita } \\
\text { - } & \text { Laooq-e-Chiraita } \\
\text { - } & \text { Jawarish-e-Chiraita } \\
\text { - } & \text { Khamira-e-Chiraita }\end{array}$ \\
\hline
\end{tabular}

3. High performance thin layer chromatography methods and validation parameters for quantification of andrographolide from andrographis paniculata and its marketed formulations.

Bhope et al. in 2009 had reported a new and precise method from HPTLC from quantitative estimation Marker Compound [Andrographolide] in Andrographis paniculata and marketed formulations. The stationary phase used was precoated [silica gel 60 F254] Aluminium plates. The mobile phase used was Methanol (2.5); Formic Acid (05); Ethyl Acetate (30): Toulene (50). The retention factor for andrographolide was found to be 0.34 and plus minus 0.03 in both case i.e pharmaceutical dosage and plant extract. The linearity was found at 100-800 ng per spot. The method is precise by relative standard deviation value was 1.52 percent and relative standard deviation for system precision was 1.38 percent. The accuracy was 97.34 plus minus 1.47 and specificity was according to ICH guidelines.
Jadhao in 2010 had reported rapid, new and accurate method for determination of marker compound andrographolide in polyherbal formulations or herbal powder from Andrographis paniculata by HPTLC method. The method contains isolation of compounds by thin layer chromatography method plates in which were precoated with silical gel $60 \mathrm{~F} 254$. The solvent system consists of benzene: ethyl acetate 5:5 [v/v]. The scanning was done through densitometric scanner (UV reflectance photomode) at 220 nano metre. The amount of andrographolide content found in test sample was 237.2 gram in per $100 \mathrm{mg}$ herbal powder and $41.80 \mathrm{mg}$ in per $5 \mathrm{ml}$ of polyherbal formulation. The linearity was $360 \mathrm{ng}$ to $660 \mathrm{ng}$ per spot and the average \% recovery was 97.68 .

Mamatha in 2010 had reported and validated HPTLC method in which Andrographolide is estimated quantitatively in A. paniculata. The technique hired TLC Aluminum (Al) precoated silica gel 60 F254 which plays are role of stationary segment with mobile 
Shweta Parihar et al., Sch Acad J Pharm, Jan, 2022; 11(1): 27-36

segment as Chloroform: Methanol 7:1v/v. Andrographolide confirmed suggest $\mathrm{Rf}$ value is 0.41 with $\lambda \max$ at $231 \mathrm{~nm}$. The approach turned into verified in phrases of linearity (100- 500ng), precision, and accuracy (100.03\% restoration). Limit of detection became 30ng and restrict of quantification 100ng. Inter day variation $1.14 \%-1.25 \%$, intraday variation $1.14 \%$ $1.58 \%$.

Jain et al. in 2010 had reported a new method for quantitative estimation of marker compound from Andrographis paniculata extract and its marketed formulations. The separation for active drug has done by chromatography on the pre-coated (silica gel 60 F254) aluminum plates which act as a stationary phase. The solvent system contains chloroform: toluene: methanol 66:26:08[v/v/v]. The retention factor of andrographolide was 0.49 . The wavelength used for analysis was 229 nano meters. The linearity range was found to be 200 to $1000 \mathrm{ng}$, limit of detection was $3.5 \mathrm{ng}$ and limit of quantification was $11.7 \mathrm{ng}$.

Patel et al. in 2012 had reported HPTLC method to quantify marker compound andrographolide in tablet and syrup formulations of Andrographis paniculata. Stationary Phase was Precoated silica 60F254 plates and Mobile Phase is toluene: acetone: formic acid (9:6:1) and detected wavelength value 254 nanometer had been used. LOD or LOQ of andrographolide was $79.28 \mathrm{ng} / \mathrm{spot}$ or $26.16 \mathrm{ng} / \mathrm{spot}$. Inter day $(n=5) 0.63$, Intraday $(n=5)$ zero 0.36 . The calibration curve was linear among 200-400 nano gram per spot for marker compound and a 100 -200nanogram per spot.

Zade et al. in 2013 had reported new, simple and precise method of validation and quantitative estimation of Andrographis paniculata and its marketed formulations (Amylcure, Livomyn, Liv-compound) through HPTLC. The solvent system used is Methanol: Chloroform in ratio $1: 9 \mathrm{v} / \mathrm{v}$ and stationary phase used was aluminiun plate 60 F254. Wavelength used for scanning andrographolide was 232 nanometer. Retention factor value for andrographolide is 0.64. Limit of detection and limit of quantification for andrographolide was $3.05 \mathrm{ng} / \mathrm{spot}$ and $18.28 \mathrm{ng} / \mathrm{spot}$. Linearity range was 200-1000 ng/spot for andrographolide.

Garg et al. in 2016 had validated balance indicating research of kalmegh by HPTLC. Stationary phase used was silica gel 60F254, cell section used chloroform: toluene: methanol (7:1.5:1.5, v/v/v), wavelength range was $254 \mathrm{~nm}$. Limit of quantification was $0.52 \mathrm{ng} / \mathrm{spot}$ and limit of detection was 1.59 ng/spot. Linear variety 100-500 ng/spot, \%RSD (n=6) 0.8686-1.74, Intraday -zero.56-1.74, Interday 67.392128.63. Linear regression equation was $\mathrm{Y}=\mathrm{mx}+\mathrm{c} \mathrm{Y}=$ $3.534 \mathrm{x}+3510$.
Pancham et al. in 2019 had reported a validated an appropriate analytical technique for the Andrographolide amount determination in its bulk powder. Ultra Voilet-Spectrophotometric approach had developed. Solvent used was methanol: water $(50: 50 \mathrm{v} / \mathrm{v})$. The wavelength used is 321 nanometer. Restriction of detection $14.71 \mathrm{ug} / \mathrm{ml}$, Limit of quantification LOQ is $44.57 \mathrm{ug} / \mathrm{ml}$, interaday version $0.868 \%-1.203 \%$, machine Precision is $1.8 \%$ Interday one was $1.51 \%$, Inter day two was $1.90 \%$, Inter day three was $1.64 \%$. Analyte confirmed linear reaction between the attention varieties of $50-250 \mu \mathrm{g} / \mathrm{mL}$. \% Relative Standard Deviations values less than two percent. An approach may be done on an excellent manage and test of andrographolide/marker compound in bulk powder of Andrographis paniculata.

\section{High-performance thin layer chromatography methods and validation parameters for quantification of other than andrographolide from andrographis paniculata and its marketed formulations.}

Akowuah et al. in 2009 had reported a new simple and rapid method for quantitative determination of 14-Deoxy-11, 12-DidehydroAndrographolide and Andrographolide with HPTLC method and RP-HPLC with UV method. The RSD i.e relative standard deviation of both the marker compound was found between range 0.86--0.99 for intra-day and 0.86-0.98 for inter-day from HPTLC method. The RSD i.e relative standard deviation of andrographolide and 14deoxy-11, 12-didehydroandrographolide was in between the range of 0.86-1.02 for intra-day and 0.871.02 for inter-day from HPLC method. Recovery range of andrographolide and 14-deoxy-11, 12didehydroandrographolide was 96.5 to 99.0 percent from HPTLC. The leaves used were of plants cultivated in different locations of Malaysia. Both fingerprinting techniques showed similar quantity of in andrographolide and 14-deoxy-11, 12didehydroandrographolide all extract.

Pawar et al. in 2010 had reported rapid and accurate HPTLC method for determination of andrographolide into variety of samples in whole part of plant Andrographis paniculata. The separation of andrographonin was done by putting spot of alcholic extract of the whole plant i.e Andrographis paniculata. Stationary phase used was pre-coated (silica gel 60 GF254) aluminum plates. The solvent system used was Formic acid (0.5); Ethyl Acetate (4.5) Toulene(5.4). The derivatizing is done by using anisaldehyde sulphuric acid reagent. The wavelength used for detection and quantitative analysis of compounds was 235 nano meter. The samples contain same amount of marker compound. The mean recovery was nearly $100 \%$ and found to be accurate. TABLE 3 showed Validation parameters of andrographolide content form Andrographis paniculata by HPTLC from different geographical areas. 
Table-3: Validation parameters of andrographolide content form Andrographis paniculata by HPTLC from different geographical areas

\begin{tabular}{|c|c|c|c|c|c|c|c|c|c|}
\hline 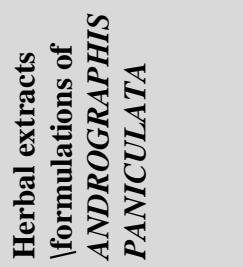 & 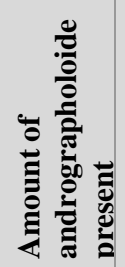 & $\simeq$ & 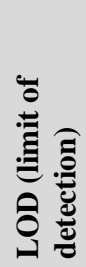 & 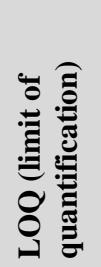 & $\begin{array}{l}2 \\
0 \\
0\end{array}$ & $\begin{array}{l}\overrightarrow{0} \\
0 \\
0 \\
0 \\
0 \\
0 \\
0 \\
0\end{array}$ & 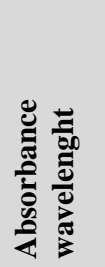 & $\begin{array}{l}\frac{0}{\tilde{z}} \\
\frac{\tilde{E}}{2} \\
\frac{0}{2} \\
\frac{0}{0}\end{array}$ & 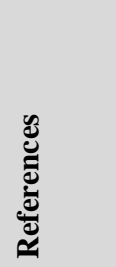 \\
\hline $\begin{array}{l}\text { Madhya Pradesh } \\
\text { (leaves of kalmegh) }\end{array}$ & $2.32 \%$ & 0.49 & $3.5 \mathrm{ng}$ & $11.7 \mathrm{ng}$ & 0.0164 & $\begin{array}{l}99.70 \pm 0.2 \\
54\end{array}$ & $229 \mathrm{~nm}$ & $\begin{array}{l}\text { Chloroform:toluene:m } \\
\text { ethanol }(66: 26: 8, \mathrm{v} / \mathrm{v} / \mathrm{v})\end{array}$ & $\begin{array}{l}\text { Jain } e t \\
\text { al.,2010 }\end{array}$ \\
\hline $\begin{array}{l}\text { Maharastra (leaves } \\
\text { of kalmegh) }\end{array}$ & $2.37 \%$ & 0.49 & $3.5 \mathrm{ng}$ & $11.7 \mathrm{ng}$ & 0.0137 & $\begin{array}{l}98.9 \pm 1.56 \\
9\end{array}$ & $229 \mathrm{~nm}$ & $\begin{array}{l}\text { Chloroform:toluene:m } \\
\text { ethanol }(66: 26: 8, \mathrm{v} / \mathrm{v} / \mathrm{v})\end{array}$ & $\begin{array}{l}\text { Jain et } \\
\text { al.,2010 }\end{array}$ \\
\hline $\begin{array}{l}\text { Uttar Pradesh } \\
\text { (leaves of kalmegh) }\end{array}$ & $2.46 \%$ & 0.49 & $3.5 \mathrm{ng}$ & $11.7 \mathrm{ng}$ & 0.0113 & $\begin{array}{l}97.8 \pm 1.06 \\
5\end{array}$ & $229 \mathrm{~nm}$ & $\begin{array}{l}\text { Chloroform:toluene:m } \\
\text { ethanol }(66: 26: 8, \mathrm{v} / \mathrm{v} / \mathrm{v})\end{array}$ & $\begin{array}{l}\text { Jain } \text { et } \\
\text { al.,2010 }\end{array}$ \\
\hline $\begin{array}{l}\text { Karnataka } \\
\text { (kalmegh leaves) }\end{array}$ & $1.19 \%$ & 0.41 & $30 \mathrm{ng}$ & $100 \mathrm{ng}$ & $1.19 \%$ & $\begin{array}{l}4.864+9.1 \\
1 * X\end{array}$ & $231 \mathrm{~nm}$ & $\begin{array}{l}\text { Chloroform:Methanol } \\
(7: 1)\end{array}$ & $\begin{array}{l}\text { Mamatha } \\
2010\end{array}$ \\
\hline $\begin{array}{l}\text { Tamil Nadu } \\
\text { (Kalmegh leaves) }\end{array}$ & $0.85 \%$ & 0.41 & $30 \mathrm{ng}$ & $100 \mathrm{ng}$ & $1.19 \%$ & $\begin{array}{l}4.864+9.1 \\
1 * X\end{array}$ & $231 \mathrm{~nm}$ & $\begin{array}{l}\text { Chloroform:Methanol } \\
(7: 1)\end{array}$ & $\begin{array}{l}\text { Mamatha } \\
2010\end{array}$ \\
\hline $\begin{array}{l}\text { Andhra Pradesh } \\
\text { (Kalmegh leaves) }\end{array}$ & $0.70 \%$ & 0.41 & $30 \mathrm{ng}$ & $100 \mathrm{ng}$ & $1.19 \%$ & $\begin{array}{l}4.864+9.1 \\
1 * X\end{array}$ & $231 \mathrm{~nm}$ & $\begin{array}{l}\text { Chloroform:Methanol } \\
(7: 1)\end{array}$ & $\begin{array}{l}\text { Mamatha } \\
2010\end{array}$ \\
\hline $\begin{array}{l}\text { Kerala (Kalmegh } \\
\text { leaves) }\end{array}$ & $0.99 \%$ & 0.41 & $30 \mathrm{ng}$ & $100 \mathrm{ng}$ & $1.19 \%$ & $\begin{array}{l}4.864+9.1 \\
1 * X\end{array}$ & $231 \mathrm{~nm}$ & $\begin{array}{l}\text { Chloroform:Methanol } \\
(7: 1)\end{array}$ & $\begin{array}{l}\text { Mamatha } \\
2010\end{array}$ \\
\hline $\begin{array}{l}\text { Bangalore } \\
\text { Andrographis } \\
\text { paniculata (AP) } \\
\text { whole plant }\end{array}$ & $97.34 \%$ & $\begin{array}{l}0.34 \\
\pm \\
0.03\end{array}$ & $30 \mathrm{ng}$ & $100 \mathrm{ng}$ & $\begin{array}{l}\text { Method } \\
\text { precision }=1.52 \\
\%, \text { system } \\
\text { precision }= \\
1.38 \%\end{array}$ & $\begin{array}{l}y=142.24 \\
x+ \\
138.05\end{array}$ & $226 \mathrm{~nm}$ & $\begin{array}{l}\text { Methanol (2.5): } \\
\text { formicacid(05):ethyl } \\
\text { acetate(30):toulene }(50)\end{array}$ & $\begin{array}{l}\text { Bhope et } \\
\text { al., } 2009\end{array}$ \\
\hline
\end{tabular}

The amount of marker compound andrographolide varies from place to place, which results in variations in the formulations also. The HPTLC method validation can resolve the quality and quantity of marker compound andrographolide.

There are different geographical conditions of different geographical areas, so the concentration of the chief constituent's andrographolide also varies. It also results in variations of marker compound in formulations.

The variations in the amount of andrographolide are due to different soil physiology and $\mathrm{pH}$ range and different climatic condition of each and every place.

To know the variations in amount of andrographolide the biosynthetic pathways were also studied. And it came to know that the enzymes, coenzymes and precursor compounds in between biosynthetic pathways has different $\mathrm{pH}$ and temperature range which affect the quantity of andrographolide in different geographic conditions. $\mathrm{pH}$ range and climatic temperature of soils and precursor compounds of andrographolide are given in table 4.2 and 4.3 respectively. TABLE 4 showed $\mathrm{pH}$ range and climatic temperature of soils of different areas (S.K. Reza et al., 2017). TABLE 5 showed $\mathrm{pH}$ range and climatic temperature of precursor compounds of andrographolide. TABLE 6 showed Validation parameters of andrographolide content form Andrographis paniculata by HPTLC from different marketed formulations. TABLE 7 showed HPTLC for other than andrographolide content from marketed formulations.

Table-4: pH range and climatic temperature of soils of different areas (S.K. Reza et al., 2017)

\begin{tabular}{|l|l|l|l|l|}
\hline $\begin{array}{l}\text { S. } \\
\text { NO }\end{array}$ & $\begin{array}{l}\text { NAME OF } \\
\text { PLACE }\end{array}$ & pH RANGE & $\begin{array}{l}\text { CLIMATIC } \\
\text { TEMPERATURE }\end{array}$ & REFERENCES \\
\hline $\mathbf{1}$ & Karnataka & $3.9-7$ & $\begin{array}{l}\text { Hot with heavy } \\
\text { rainfall }\end{array}$ & $\begin{array}{l}\text { http://saspublisher.com/wp-content/uploads/2013/10/SAJB-15200- } \\
\text { 208.pdf }\end{array}$ \\
\hline $\mathbf{2}$ & Kerela & $3.5-5.5$ & $28-32$ degree c & $\begin{array}{l}\text { https://www.keralasoilfertility.net/en/laterites.jsp\#: :text=More\%20 } \\
\text { than\%2090\%2 } \\
\text { 0per\%20cent,with\%20lime\%20to\%20alleviate\%20acidity }\end{array}$ \\
\hline $\mathbf{3}$ & $\begin{array}{l}\text { Andhra } \\
\text { Pradesh }\end{array}$ & $6.5-8$ & Hot and humid & $\begin{array}{l}\text { https://andhrapradesh.pscnotes.com/andhra-general-studies/soils-of- } \\
\text { andhra pradesh/ }\end{array}$ \\
\hline $\mathbf{4}$ & $\begin{array}{l}\text { Madhya } \\
\text { Pradesh }\end{array}$ & $5.5-8.5$ & Subtropical climate & $\begin{array}{l}\text { https://madhyapradesh.pscnotes.com/madhya-pradesh-gk/madhya- } \\
\text { pradesh geography/soils-of-madhya } \\
\text { pradesh/\#: :text=The\%20pH\%20level\%20of\%20these,\%2C\%20Sid } \\
\text { hi\%2C\%20K } \\
\text { atni\%2C\%20Umaria.\&text=This\%20type\%20of\%20soils\%20is,mat } \\
\text { ter\%20and\%2 0Phosphorous\%20is\%20less }\end{array}$ \\
\hline
\end{tabular}


Shweta Parihar et al., Sch Acad J Pharm, Jan, 2022; 11(1): 27-36

\begin{tabular}{|l|l|l|l|l|}
\hline $\begin{array}{l}\text { S. } \\
\text { NO }\end{array}$ & $\begin{array}{l}\text { NAME OF } \\
\text { PLACE }\end{array}$ & pH RANGE & $\begin{array}{l}\text { CLIMATIC } \\
\text { TEMPERATURE }\end{array}$ & REFERENCES \\
\hline $\mathbf{5}$ & $\begin{array}{l}\text { Uttar } \\
\text { Pradesh }\end{array}$ & $6.9-9.5$ & $\begin{array}{l}\text { Fluctuating from 0-32 } \\
\text { degree C }\end{array}$ & $\begin{array}{l}\text { https://www.researchgate.net/figure/Soil-pH-status-in-four-selected- } \\
\text { districts-of eastern-Uttar-Pradesh_tbl1_283203171 }\end{array}$ \\
\hline $\mathbf{6}$ & Bangalore & $4.6-5$ & 28-32 degree C & $\begin{array}{l}\text { https://www.researchgate.net/figure/Soil-pH-CaCl2-in-ab-clay- } \\
\text { loam-BCL-red } \\
\text { loam-RL-and-brown-sandy-loam-BSL- }\end{array}$ \\
\hline
\end{tabular}

Table-5: pH range and climatic temperature of precursor compounds of andrographolide

\begin{tabular}{|l|l|l|l|l|}
\hline S.NO & PRECURSORS NAME & $\begin{array}{l}\text { pH } \\
\text { RANGE }\end{array}$ & TEMPERATURE & REFERENCES \\
\hline 1 & IPP [Isopenteyl Pyrophosphate] & $7-7.8$ & 4 degree C & Valdiva et al. 1997 \\
\hline 2 & DMAPP [Dimethylalallyl pyrophosphate]. & 7 & Not mention & Takahashi et al. 1999 \\
\hline 3 & DXP [Deoxyxylulose] & $5.5-9.0$ & Not mention & Bailey et al. 2002 \\
\hline 4 & MVA [Mevalonic acid] pathways. & $7-10$ & Not mention & Schulte et al. 2000 \\
\hline 5 & HMGO coenzyme A & 7.2 & Not mention & Takahashi et al. 1999 \\
\hline 6 & Acetyl coenzyme A & $4.7-9.0$ & Not mention & Walker et al. 1999 \\
\hline
\end{tabular}

Table-6: Validation parameters of andrographolide content form Andrographis paniculata by HPTLC from different marketed formulations

\begin{tabular}{|c|c|c|c|c|c|c|c|c|c|}
\hline 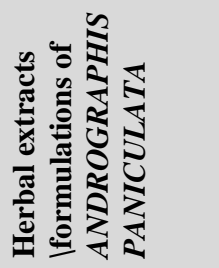 & 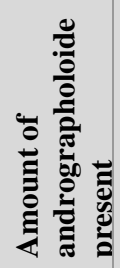 & 秃 & 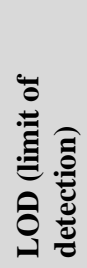 & 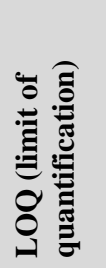 & 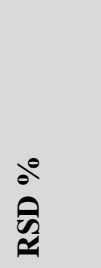 & $\begin{array}{l}\overrightarrow{0} \\
0 \\
0 \\
0 \\
0 \\
0 \\
0 \\
0\end{array}$ & 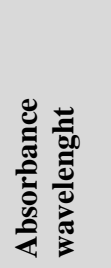 & 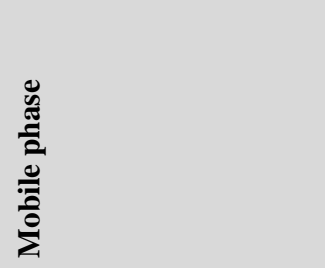 & $\frac{\mathscr{U}}{0}$ \\
\hline $\begin{array}{l}\text { Formulation } 1 \\
\text { (20 tablets, } \\
600 \mathrm{mg} \text { wt.) }\end{array}$ & $1.28 \%$ & 0.49 & $\begin{array}{l}3.5 \\
\mathrm{ng}\end{array}$ & $11.7 \mathrm{ng}$ & 0.0135 & $96.8 \pm 1.05$ & $229 \mathrm{~nm}$ & $\begin{array}{l}\text { Chloroform:toluene:meth } \\
\text { anol }(66: 26: 8, \mathrm{v} / \mathrm{v} / \mathrm{v})\end{array}$ & $\begin{array}{l}\text { Jain } e t \\
\text { al.,2010 }\end{array}$ \\
\hline $\begin{array}{l}\text { Formulation } 2 \\
\text { (20 tablets, } \\
600 \mathrm{mg} \text { wt.) }\end{array}$ & $1.68 \%$ & 0.49 & $\begin{array}{l}3.5 \\
\mathrm{ng}\end{array}$ & $11.7 \mathrm{ng}$ & 0.0175 & $98.0 \pm 0.75$ & $229 \mathrm{~nm}$ & $\begin{array}{l}\text { Chloroform:toluene:meth } \\
\text { anol }(66: 26: 8, \mathrm{v} / \mathrm{v} / \mathrm{v})\end{array}$ & $\begin{array}{l}\text { Jain } e t \\
\text { al.,2010 }\end{array}$ \\
\hline $\begin{array}{l}\text { Formulation } 3 \\
\text { (20 tablets, } \\
600 \mathrm{mg} \text { wt.) }\end{array}$ & $1.41 \%$ & 0.49 & $\begin{array}{l}3.5 \\
\mathrm{ng}\end{array}$ & $11.7 \mathrm{ng}$ & 0.0261 & $98.5 \pm 2.61$ & $229 \mathrm{~nm}$ & $\begin{array}{l}\text { Chloroform:toluene:meth } \\
\text { anol }(66: 26: 8, \mathrm{v} / \mathrm{v} / \mathrm{v})\end{array}$ & $\begin{array}{l}\text { Jain } e t \\
\text { al.,2010 }\end{array}$ \\
\hline $\begin{array}{l}\text { Formulation } 4 \\
\text { (20 tablets, } \\
600 \mathrm{mg} \text { wt.) }\end{array}$ & $1.05 \%$ & 0.49 & $\begin{array}{l}3.5 \\
\mathrm{ng}\end{array}$ & $11.7 \mathrm{ng}$ & 0.0273 & $98.96 \pm 1.66$ & $229 \mathrm{~nm}$ & $\begin{array}{l}\text { Chloroform:toluene:meth } \\
\text { anol }(66: 26: 8, \mathrm{v} / \mathrm{v} / \mathrm{v})\end{array}$ & $\begin{array}{l}\text { Jain } e t \\
\text { al.,2010 }\end{array}$ \\
\hline $\begin{array}{l}\text { olyherbal Asava } \\
\text { (Kalmegh) }\end{array}$ & $\begin{array}{l}41.80 \\
\mathrm{mg} / \\
5 \mathrm{ml}\end{array}$ & 0.10 & & & 1.080 & $97.68 \%$ & $220 \mathrm{~nm}$ & $\begin{array}{l}\text { Benzene:ethyl acetate } \\
(5: 5)\end{array}$ & $\begin{array}{l}\text { Jadhao } \\
2010\end{array}$ \\
\hline $\begin{array}{l}\text { Herbal powder } \\
\text { (Kalmegh) }\end{array}$ & $\begin{array}{l}237.2 \\
\mathrm{ug} / 100 \\
\mathrm{mg}\end{array}$ & 0.10 & & & 1.080 & $97.68 \%$ & $220 \mathrm{~nm}$ & $\begin{array}{l}\text { Benzene:ethyl acetate } \\
(5: 5)\end{array}$ & $\begin{array}{l}\text { Jadhao } \\
2010\end{array}$ \\
\hline $\begin{array}{l}\text { Amylcure } \\
\text { (kalmegh } \\
\text { marketed } \\
\text { formulation) }\end{array}$ & $\begin{array}{l}585.24 \\
\text { ng }\end{array}$ & 0.64 & 3.05 & 18.29 & 0.551 & $99.13 \pm 0.16$ & $232 \mathrm{~nm}$ & $\begin{array}{l}\text { Chloroform:Methanol } \\
{[9: 1]}\end{array}$ & $\begin{array}{l}\text { Zade et al. } \\
2013\end{array}$ \\
\hline $\begin{array}{l}\text { Livomyn } \\
\text { (kalmegh } \\
\text { marketed } \\
\text { formulation) }\end{array}$ & $\begin{array}{l}175.23 \\
\mathrm{ng}\end{array}$ & 0.64 & 3.05 & 18.29 & 0.501 & $99.45 \pm 0.17$ & $232 \mathrm{~nm}$ & $\begin{array}{l}\text { Chloroform:Methanol } \\
{[9: 1]}\end{array}$ & $\begin{array}{l}\text { Zade et al. } \\
2013\end{array}$ \\
\hline $\begin{array}{l}\text { Liv-Compund } \\
\text { (kalmegh } \\
\text { marketed } \\
\text { formulation) }\end{array}$ & $\begin{array}{l}407.14 \\
\text { ng }\end{array}$ & 0.64 & 3.05 & 18.29 & 0.588 & $99.32 \pm 0.16$ & $232 \mathrm{~nm}$ & $\begin{array}{l}\text { Chloroform:Methanol } \\
{[9: 1]}\end{array}$ & $\begin{array}{l}\text { Zade et al. } \\
2013\end{array}$ \\
\hline
\end{tabular}

Table-7: HPTLC for other than andrographolide content from marketed formulations

\begin{tabular}{|l|l|l|l|l|l|l|l|}
\hline $\begin{array}{l}\text { Marketed } \\
\text { formulation }\end{array}$ & $\begin{array}{l}\text { Chemical } \\
\text { constituents }\end{array}$ & LOD & LOQ & $\begin{array}{l}\text { RF } \\
\text { value }\end{array}$ & Mobile Phase & $\begin{array}{l}\text { Wavelen } \\
\text { ght }\end{array}$ & References \\
\hline $\begin{array}{l}\text { Navayas Loha } \\
\text { (Ayurvedic } \\
\text { formulation) }\end{array}$ & Andrographonin & $\begin{array}{l}99.60 \\
\%\end{array}$ & $\begin{array}{l}0.05194 \\
\% \mathrm{w} / \mathrm{w}\end{array}$ & 0.57 & $\begin{array}{l}\text { Toulene:Ethyleacetate:For } \\
\text { mic acid (5:4:1) }\end{array}$ & $235 \mathrm{~nm}$ & $\begin{array}{l}\text { Pawar } \text { et. al., } \\
2011\end{array}$ \\
\hline
\end{tabular}


Shweta Parihar et al., Sch Acad J Pharm, Jan, 2022; 11(1): 27-36

There was a large amount of variations in amount of andrographolide in different formulations of Andrographis paniculata. But the validation and HPTLC method was able to adequately resolve the standard and quantify it. TABLE 8 showed Validation by HPTLC for other than andrographolide content from crude drug

Table-8: Validation by HPTLC for other than andrographolide content from crude drug

\begin{tabular}{|c|c|c|c|c|c|c|c|c|c|}
\hline 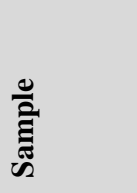 & 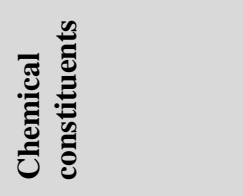 & 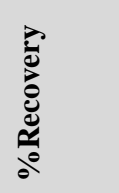 & 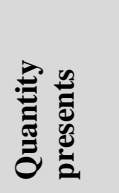 & อิ & है & 先 & 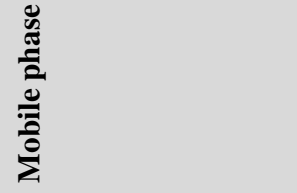 & 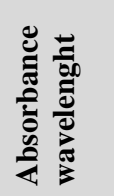 & 这 \\
\hline Kalmegh & $\begin{array}{l}\text { 14-deoxy-11, 12- } \\
\text { didehydroandrogr } \\
\text { apholide }\end{array}$ & $\begin{array}{l}96.5- \\
99.0 \%\end{array}$ & $\begin{array}{l}21.7- \\
26.9 \\
\mathrm{mg} / \mathrm{g}\end{array}$ & $\begin{array}{l}3.6 \\
\mathrm{ug} / \\
\mathrm{ml}\end{array}$ & $\begin{array}{l}1.47 \\
\%\end{array}$ & 0.43 & $\begin{array}{l}\text { Chloroform:methanol } \\
(8: 2)\end{array}$ & $254 \mathrm{~nm}$ & $\begin{array}{l}\text { Akhow } \\
\text { a } \text { et al., } \\
2009\end{array}$ \\
\hline $\begin{array}{l}\text { Kalmegh } \\
\text { [whole } \\
\text { plant] }\end{array}$ & Andrographonin & $99.82 \%$ & $\begin{array}{l}0.04966 \\
\% \mathrm{w} / \mathrm{w}\end{array}$ & & & 0.57 & $\begin{array}{l}\text { Toulene:Ethyleacetate } \\
\text { :Formic acid }(5: 4: 1)\end{array}$ & $235 \mathrm{~nm}$ & $\begin{array}{l}\text { Pawar } \\
\text { et al., } \\
2011 \\
\end{array}$ \\
\hline
\end{tabular}

Validation and HPTLC of other then marker compound was also done. The name of the chemical constituents is 14-Deoxy-11, 12DidehydroAndrographolide and Andrographonin which is also present in Andrographis paniculata. The limit of detection for 14-deoxy-11, 12didehydroandrographolide is $3.6 \mathrm{ug} / \mathrm{ml}$ and quantity of 14-deoxy-11, 12-didehydroandrographolide present is 21.7-26.9 mg/g.

\section{CONCLUSION}

In the present work 'to review high performance thin layer chromatography methods and validation parameters for quantification of andrographolide from andrographis paniculata and its marketed formulations", all the relevant information regarding Andrographis paniculata and its marketed formulations was collected from various research articles, review articles and availability of Andrographis paniculata formulations in the market. Quality and quantity of Andrographis paniculata varies due to the different geographical conditions of different geographical areas. So, the concentration of the chief constituent andrographolide also varies. It also results in variations of marker compound in formulations. The variations in the amount of andrographolide are due to different soil physiology and $\mathrm{pH}$ range and different climatic condition of each and every place. To know the variations in amount of andrographolide the biosynthetic pathways were also studied. And it came to know that the enzymes, coenzymes and precursor compounds in between biosynthetic pathways has different $\mathrm{pH}$ and temperature range which affect the quantity of andrographolide in different geographic conditions. So, there is a need to maintain its quality.

\section{ACKNOWLEDGEMENTS}

The authors are highly grateful for regular encouragement from Professors, Department of Pharmaceutical Sciences, Maharishi Dayanand University, Rohtak.

\section{REFERENCES}

- Aiyalu, R., Ramasamy, A., Mathew, L. (2016). A systematic comprehensive review on therapeutic potential of Andrographis paniculata (burm. F.) Wall. Ex nees. Journal of pharmacognosy and phytochemistry, 5(5), 189-199.

- Akowuah, G. A., Zhari, I., Norhayati, I., \& Mariam, A. (2006). HPLC and HPTLC densitometric determination of andrographolides and antioxidant potential of Andrographis paniculata. Journal of Food Composition and Analysis, 19(2-3), 118-126.

- Bailey, A. M., Mahapatra, S., Brennan, P. J., \& Crick, D. C. (2002). Identification, cloning, purification, and enzymatic characterization of Mycobacterium tuberculosis 1-deoxy-D-xylulose 5-phosphate synthase. Glycobiology, 12(12), 813 820.

- Bharati, B. D., Sharma, P. K., Kumar, N., Dudhe, R., \& Bansal, V. (2011). Pharmacological activity of Andrographis paniculata: a brief review. Pharmacologyonline, 2(1), 10.

- Bhope, S. G., Nagore, D. H., Kuber, V. V., Gupta, P. K., \& Patil, M. J. (2011). Design and development of a stable polyherbal formulation based on the results of compatibility studies. Pharmacognosy research, 3(2), 122.

- Chao, W. W., Kuo, Y. H., \& Lin, B. F. (2010). Anti-inflammatory activity of new compounds from Andrographis paniculata by NF- $\kappa \mathrm{B}$ transactivation inhibition. Journal of agricultural and food chemistry, 58(4), 2505-2512.

- Chaudhary, K., Parihar, S., \& Sharma, D. (2021). A Critical Review on Nanoscience Advancement: In Treatment of Viral Infection. Journal of Drug Delivery and Therapeutics, 11(6), 225-237.

- $\quad$ Garg, C., Sharma, P., Satija, S., \& Garg, M. (2016). Stability indicating studies of Andrographis paniculata extract by validate HPTLC protocol. Journal of Pharmacognosy and Phytochemistry, 5(6), 337-344. 
- Hossain, M. S., Urbi, Z., Sule, A., Hafizur Rahman, K. M. (2014). Andrographis paniculata (Burm. f.) Wall. ex Nees: a review of ethnobotany, phytochemistry, and pharmacology. The Scientific World

Journal. https://doi.org/10.1155/2014/274905

- Jadhao, M. (2010). Estimation of andrographolide in herbal powder and polyherbal asava by HPTLC. International journal of pharma and bio sciences, 1(4).

- Jain, P. K., Ravichandran, V., Jain, P. K., \& Agrawal, R. K. (2010). High-performance thin layer chromatography method for estimation of andrographolide in herbal extract and polyherbal formulations. Journal of Saudi Chemical Society, 14(4), 383-389.

- Jain, P. K., Ravichandran, V., Jain, P. K., \& Agrawal, R. K. (2010). High-performance thin layer chromatography method for estimation of andrographolide in herbal extract and polyherbal formulations. Journal of Saudi Chemical Society, 14(4), 383-389.

- Kulkarni, K., Jagtap, G., \& Magdum, S. (2019). A comprehensive review on herbal drug standardization. Am. J. PharmTech Res, 9, 97-122.

- Kumar, V., \& Kumar, V. (2009). An overview of herbal medicine. Int. J. Ph. Sci, 1(1), 1-20.

- Lavanya, C. G., Ravisankar, P., Akhil, K. G., Mounika, K., \& Srinivasa, B. P. (2020). Analytical method validation parameters-An updated review. Int. J. Pharm. Sci. Rev. Res, 61, 1-7.

- Lee, Y. C., Lin, H. H., Hsu, C. H., Wang, C. J., Chiang, T. A., \& Chen, J. H. (2010). Inhibitory effects of andrographolide on migration and invasion in human non-small cell lung cancer A549 cells via down-regulation of PI3K/Akt signaling pathway. European journal of pharmacology, 632(1-3), 23-32.

- Lin, F. L., Wu, S. J., Lee, S. C., \& Ng, L. T. (2009). Antioxidant, antioedema and analgesic activities of Andrographis paniculata extracts and their active constituent andrographolide. Phytotherapy Research: An International Journal Devoted to Pharmacological and Toxicological Evaluation of Natural Product Derivatives, 23(7), 958-964.

- $\quad$ Liu, C., Nadiminty, N., Tummala, R., Chun, J. Y., Lou, W., Zhu, Y., ... \& Gao, A. C. (2011). Andrographolide targets androgen receptor pathway in castration-resistant prostate cancer. Genes \& cancer, 2(2), 151-159.

- Lu, B., Sheng, Y., Zhang, J., Zheng, Z., Ji, L. (2016). The altered microRNA profile in andrographolide-induced inhibition of hepatoma tumor growth. Gene, 588(2), 124-133. https://doi.org/10.1016/j.gene.2016.05.012.

- Lu, W. J., Lee, J. J., Chou, D. S., Jayakumar, T., Fong, T. H., Hsiao, G., Sheu, J. R. (2011). A novel role of andrographolide, an NF-kappa B inhibitor, on inhibition of platelet activation: the pivotal mechanisms of endothelial nitric oxide synthase/cyclic GMP. Journal of molecular medicine (Berlin, Germany), 89(12), 1261-1273. https://doi.org/10.1007/s00109-011-0800-0

- Malahubban, M., Alimon, A. R., Sazili, A. Q., Fakurazi, S., Zakry, F. A. (2013). Phytochemical analysis of Andrographis paniculata and Orthosiphon stamineus leaf extracts for their antibacterial and antioxidant potential. Tropical biomedicine, 30(3), 467-480.

- Mamatha A. (2010). Quantitative HPTLC analysis of andrographolide in Andrographis paniculata obtained from different geographical sources (India). International journal of pharmacy and pharmaceutical sciences, 3(2); 0975-1491.

- Mandal, D., Dash, S. K., Das, B., Chattopadhyay, S., Ghosh, T., Das, D., \& Roy, S. (2016). Biofabricated silver nanoparticles preferentially targets Gram positive depending on cell surface charge. Biomedicine \& Pharmacotherapy, 83, 548558.

- Menhard, B., \& Zenk, M. H. (1999). Purification and characterization of acetyl coenzyme A: 10hydroxytaxane omicron-acetyltransferase from cell suspension cultures of Taxus chinensis. Phytochemistry, 50, 763-774.

- Mishra, S. K., Sangwan, N. S., \& Sangwan, R. S. (2007). Phcog rev.: Plant review Andrographis paniculata (Kalmegh): A review. Pharmacognosy Reviews, 1(2), 283-298.

- Nadiminty, N., Lou, W., Sun, M., Chen, J., Yue, J., Kung, H. J., ... \& Gao, A. C. (2010). Aberrant activation of the androgen receptor by $\mathrm{NF}-\kappa \mathrm{B} 2 / \mathrm{p} 52$ in prostate cancer cells. Cancer research, 70(8), 3309-3319.

- Niranjan, A., Tewari, S. K., \& Lehri, A. (2010). Biological activities of kalmegh (Andrographis paniculata Nees).

- Nyeem, M. A. B., Mannan, M. A., Nuruzzaman, M., Kamrujjaman, K. M., \& Das, S. K. (2017). Indigenous king of bitter (Andrographis paniculata): A review. Journal of Medicinal Plants Studies, 5(2), 318-324.

- Pancham, Y., Patil, N., Girish, B., \& Mannur, V. (2019). Development and validation of analytical method for determination of andrographolide in bulk powder. Int J Pharma Res Health Sci,7(1), 2899-2903.

- Pandey, G., Rao, C. (2017). Andrographis Paniculata wall. ex Nees : Its Traditional Use , Secondary Metabolite Production, Phytochemistry , Pharmacology and Products Developed.

- $\quad$ Parihar, S., \& Sharma, D. (2021). A breif overview on asparagus racemous. IJRAR, 8(4), 959-971.

- Parihar, S., \& Sharma, D. (2021). A Breif Overview on Vitis vinifera. Sch Acad J Pharm, 12, 231-239. 
- Parihar, S., \& Sharma, D. A Brief Overview on Crinum Latifolium. IJSR, 10(12), 725-728.

- Parihar, S., Sharma, D. (2021). Cynodondactylon: A Review of Pharmacological Activities. Sch Acad J Pharm, 11; 183-189.

- Parihar, S., Sharma, D. (2021). Navagraha (nine planets) plants: the traditional uses and the therapeutic potential of nine sacred plants of india that symbolises nine planets. IJRAR, 8(4), 96-108.

- Pawar, R. K., SHARMA, S., Singh, K. C., \& SHARMA, K. R. (2010). Development and validation of HPTLC method for the determination of andrographolide from Andrographis paniculata (whole plant). International Journal of Chemistry Research, 15-19.

- Rafat, A., Philip, K., \& Muni, S. (2010). Antioxidant potential and content of phenolic compounds in ethanolic extracts of selected parts of Andrographis paniculata. Journal of Medicinal Plants Research, 4(3), 197-202.

- Rashmin, P., Mrunali, P., \& BHARAT, P. (2012). HPTLC method development and validation: strategy to minimize methodological failures. Journal of food and drug analysis, 20(4).

- $\quad$ Rivera, D. S., Lindsay, C., Codocedo, J. F., Morel, I., Pinto, C., Cisternas, P., ... \& Inestrosa, N. C. (2016). Andrographolide recovers cognitive impairment in a natural model of Alzheimer's disease (Octodon degus). Neurobiology of aging, 46, 204-220.

- Samy, R. P., Thwin, M. M., \& Gopalakrishnakone, P. (2007). Phytochemistry, pharmacology and clinical use of Andrographis paniculata. Natural Product Communications, 2(5), $1934578 X 0700200519$.

- Samy, R. P., Thwin, M. M., \& Gopalakrishnakone, P. (2007). Phytochemistry, pharmacology and clinical use of Andrographis paniculata. Natural Product Communications, 2(5), $1934578 X 0700200519$.

- Sareer, O., Ahmad, S., \& Umar, S. (2014). Andrographis paniculata: a critical appraisal of extraction, isolation and quantification of andrographolide and other active constituents. Natural product research,28(23), 2081-2101.

- Shen, Y. C., Chen, C. F., \& Chiou, W. F. (2002). Andrographolide prevents oxygen radical production by human neutrophils: possible mechanism (s) involved in its anti-inflammatory effect. British journal of pharmacology, 135(2), 399-406.

- Shewiyo, D. H., Kaale, E. A. K. K., Risha, P. G., Dejaegher, B., Smeyers-Verbeke, J., \& Vander Heyden, Y. (2012). HPTLC methods to assay active ingredients in pharmaceutical formulations: A review of the method development and validation steps. Journal of pharmaceutical and biomedical analysis, 66, 11-23.
- Shi, M. D., Lin, H. H., Lee, Y. C., Chao, J. K., Lin, R. A., \& Chen, J. H. (2008). Inhibition of cell-cycle progression in human colorectal carcinoma Lovo cells by andrographolide. Chemico-biological interactions, 174(3), 201-210.

- Singh, B., Sehgal, H. (2018). A Scientific Study of Kalmegh I.E. Andrographis Paniculata (Burm.f.) Wall. Ex. Nees. Int J Recent Sci Res. 9(2), pp. 24409-24412.

DOI: http://dx.doi.org/10.24327/ijrsr.2018.0902.16 56

- SKDM. Siddha and ayurvedha company (india) limited. (2010). The siddha system of medicine is an indigenous traditional system. 9-23.

- Sonia, K., Shree, B.S., Lakshmi, K.S. (2017). HPTLC method development and validation: An overview. Journal of Pharmaceutical Sciences and Research, 9; 652-657.

- $\quad$ Sowjanya, P., Subashini, D., Lakshmi, R.K. (2015). Analytical validation parameters. Journal of pharmaceutical analysis.

- Srivastava, A., Misra, H., Verma, R. K., \& Gupta, M. M. (2004). Chemical fingerprinting of Andrographis paniculata using HPLC, HPTLC and densitometry. Phytochemical Analysis: An International Journal of Plant Chemical and Biochemical Techniques, 15(5), 280-285.

- Subramanian, R., Asmawi, M. Z., \& Sadikun, A. (2008). Effect of andrographolide and ethanol extract of Andrographis paniculata on liver glycolytic, gluconeogenic, and lipogenic enzymes in a type 2 diabetic rat model. Pharmaceutical Biology, 46(10-11), 772-780.

- Subramanian, R., Asmawi, M. Z., \& Sadikun, A. (2012). A bitter plant with a sweet future? A comprehensive review of an oriental medicinal plant: Andrographis paniculata. Phytochemistry reviews, 11(1), 39-75.

- Suebsasana, S., Pongnaratorn, P., Sattayasai, J., Arkaravichien, T., Tiamkao, S., \& Aromdee, C. (2009). Analgesic, antipyretic, anti-inflammatory and toxic effects of andrographolide derivatives in experimental animals. Archives of pharmacal research, 32(9), 1191-1200.

- Suzuki, R., Matsushima, Y., Okudaira, N., Sakagami, H., \& Shirataki, Y. (2016). Cytotoxic components against human oral squamous cell carcinoma isolated from Andrographis paniculata. Anticancer research,36(11), 59315935.

- Takahashi, I., Ojima, N., Ogura, K., \& Seto, S. (1978). Purification and characterization of dimethylallyl pyrophosphate: aspulvinone dimethylallyltransferase from Aspergillus terreus. Biochemistry, 17(13), 2696-2702.

- Takahashi, S., Kuzuyama, T., \& Seto, H. (1999). Purification, characterization, and cloning of a eubacterial 3-hydroxy-3-methylglutaryl coenzyme A reductase, a key enzyme involved in biosynthesis 
of terpenoids. Journal of Bacteriology, 181(4), 1256-1263.

- Tan, H. K., Muhammad, T. S. T., \& Tan, M. L. (2016). Cytotoxic data of 14-deoxy-11, 12didehydroandrographolide (14-DDA), double transfection and DDIT3 silencing data in T-47D breast carcinoma cells. Data in brief, 7, 1506-1510.

- Tanwar, A., Chawla, R., Chakotiya, A. S., Thakur, P., Goel, R., Basu, M., \& Khan, H. A. (2016). Effect of Holarrhena antidysentrica (Ha) and Andrographis paniculata (Ap) on the biofilm formation and cell membrane integrity of opportunistic pathogen Salmonella typhimurium. Microbial pathogenesis, 101, 76-82.

- Telrandhe, U. B., Lokhande, R. R., Lodhe, V. N., Kosalge, S. B., Parihar, S., \& Sharma, D. (2021). Review on Herbal Drugs used in Dental Care Management. Asian Journal of Pharmaceutical Research and Development, 9(6), 71-79.

- Vasu, S., Palaniyappan, V., \& Badami, S. (2010). A novel microwave-assisted extraction for the isolation of andrographolide from Andrographis paniculata and its in vitro antioxidant activity. Natural product research,24(16), 15601567.

- Verma, H., Negi, M. S., Mahapatra, B. S., Shukla, A., \& Paul, J. (2019). Evaluation of an emerging medicinal crop Kalmegh [Andrographis paniculata (Burm. F.) Wall. Ex. Nees] for commercial cultivation and pharmaceutical \& industrial uses: A review. J. Pharmacogn. Phytochem, 8, 835-848.

- Verma, R. K., Verma, S. K., Pankaj, U., Gupta, A. K., Khan, K., \& Shankar, K. (2015). Improvement in the yield and quality of kalmegh (Andrographis paniculata Nees) under the sustainable production system. Natural product research, 29(3), 297-300.

- Walker, K., Ketchum, R. E., Hezari, M., Gatfield, D., Goleniowski, M., Barthol, A., \& Croteau, R. (1999). Partial Purification and Characterization of Acetyl Coenzyme A: Taxa-4 (20), 11 (12)-dien-5 $\alpha$ olO-Acetyl Transferase That Catalyzes the First Acylation Step of Taxol Biosynthesis. Archives of biochemistry and biophysics, 364(2), 273-279.

- Wang, W., Guo, W., Li, L., Fu, Z., Liu, W., Gao, J., \& Gu, Y. (2016). Andrographolide reversed 5FU resistance in human colorectal cancer by elevating BAX expression. Biochemical pharmacology, 121, 8-17.

- Wong, S. Y., Tan, M. G., Wong, P. T., Herr, D. R., \& Lai, M. K. (2016). Andrographolide induces Nrf2 and heme oxygenase 1 in astrocytes by activating p38 MAPK and ERK. Journal of neuroinflammation, 13(1), 1-12.

- Xu, F., Wu, H., Zhang, K., Lv, P., Zheng, L., \& Zhao, J. (2016). Pro-neurogenic effects of andrographolide on RSC96 Schwann cells in vitro. Molecular medicine reports, 14(4), 35733580.

- Yadav, J.S., Singh, T.P. (2012). Phytochemical analysis and antifungal activity of Andrographis paniculata. Int J Pharm Res Biosci, 1; 240-263.

- Yang, T., Yao, S., Zhang, X., \& Guo, Y. (2016). Andrographolide inhibits growth of human T-cell acute lymphoblastic leukemia Jurkat cells by downregulation of PI3K/AKT and upregulation of p38 MAPK pathways. Drug design, development and therapy, 10, 1389-1397. https://doi.org/10.2147/DDDT.S94983

- Yu, B. C., Hung, C. R., Chen, W. C., Cheng, J. T. (2003). Antihyperglycemic effect of andrographolide in streptozotocin-induced diabetic rats. Planta medica, 69(12), 1075-1079. https://doi.org/10.1055/s-2003-45185

- Yuan, H., Sun, B., Gao, F., \& Lan, M. (2016). Synergistic anticancer effects of andrographolide and paclitaxel against A549 NSCLC cells. Pharmaceutical biology, 54(11), 2629-2635. https://doi.org/10.1080/13880209.2016.1176056

- Yue, G. G., Lee, J. K., Li, L., Chan, K. M., Wong, E. C., Chan, J. Y., Fung, K. P., Lui, V. W., Chiu, P. W., \& Lau, C. B. (2015). Andrographis paniculata elicits anti-invasion activities by suppressing TM4SF3 gene expression and by anoikissensitization in esophageal cancer cells. American journal of cancer research, 5(12), 3570-3587.

- Zade, S.R., Priya, B., Bagmar, U.R., \& Ganjiwale, R.O. (2013). Development and validation of HPTLC method for estimation of hepatoprotective diterpenoid andrographolide in polyherbal formulations. International Journal of pharmaceutical sciences, 5:3.

- Zhang, X. F., \& Tan, B. K. (2000). Anti-diabetic property of ethanolic extract of Andrographis paniculata in streptozotocin-diabetic rats. Acta pharmacologica Sinica, 21(12), 1157-1164.

- Zhou, J., Ong, C. N., Hur, G. M., Shen, H. M. (2010). Inhibition of the JAK-STAT3 pathway by andrographolide enhances chemosensitivity of cancer cells to doxorubicin. Biochemical pharmacology, 79(9), 1242-1250. https://doi.org/10.1016/j.bcp.2009.12.014

- Zou, W., Xiao, Z., Wen, X., Luo, J., Chen, S., Cheng, Z., Xiang, D., Hu, J., He, J. (2016). The anti-inflammatory effect of Andrographis paniculata (Burm. f.) Nees on pelvic inflammatory disease in rats through down-regulation of the NF$\kappa \mathrm{B}$ pathway. BMC complementary and alternative medicine, 16(1), https://doi.org/10.1186/s12906-016-1466-5 